\title{
Banal Politik Transaksional Para Pemilih (Tinjauan Psikologis)
}

\author{
Haressa Lintang Rizkika \\ Fakultas Psikologi, Universitas Muhammadiyah Jember \\ lintangrizkika@gmail.com \\ Hikmatul Ummah \\ Fakultas Psikologi, Universitas Muhammadiyah Jember \\ hikmatulummah72@gmail.com \\ Aidina Winona Raider \\ Fakultas Psikologi, Universitas Muhammadiyah Jember \\ aydina_winona@yahoo.com \\ Erna Ipak Rahmawati, S.Psi,MA. \\ Fakultas Psikologi, Universitas Muhammadiyah Jember \\ ipakrahmawati@unmuhjember.ac.id
}

\begin{abstract}
Organizing a democratic party - general election (Election) - in Indonesia today is no stranger to the term 'money politics' or transactional politics. Ideally, a political choice in a democratic party is based on an interest in the candidate's vision and mission or based on shared ideology and is carried out in accordance with the values and norms that exist in society. But in fact, transactional politics have been commonplace from the biggest political event to the lowest level or in other terms to be 'banal' or considered normal in our society. This study uses a qualitative approach with a phenomenological study in which the results are a description of the psychological dynamics of transactional political actors in this case the voters. The results obtained that in the review of the dynamics field theory of the principals began with a motivation symbolized as a V (Vector) towards the goal in the form of money without significant obstacles or permeable bondaries in the psychological environment of the research subject. In the typology of the personal living space symbolized as (P) believing that; 1) Giving is considered a representation of prosocial actions; 2) Giving is something that is considered not violating the values and norms of individuals and society; 3) Individuals have the resources and opportunity to conduct transactional politics.
\end{abstract}

Keywords: transactional political banal; psychology; field theory 


\begin{abstract}
Abstrak
Penyelenggaraan pesta demokrasi - pemilihan umum (Pemilu) - di Indonesia saat ini sudah tidak asing dengan istilah 'money politic' atau politik transaksional. Idealnya sebuah pilihan politik dalam pesta demokrasi didasari oleh ketertarikan akan visi-misi kandidat atau berdasarkan kesamaan ideologi serta dilaksanakan sesuai dengan nilai-nilai dan norma yang ada di masyarakat. Namun pada kenyataanya, politik transaksional sudah lumrah dilakukan dari hajat politik yang paling besar sampai ke tingkat yang paling kecil atau dalam istilah lain menjadi 'banal' atau dianggap wajar di dalam masyarakat kita. Penelitian ini menggunakan pendekatan kualitatif dengan studi fenomenologis dimana hasilnya berupa gambaran dinamika psikologis dari para pelaku politik transaksional dalam hal ini adalah para pemilih. Hasil penelitian diperoleh bahwa dalam tinjauan teori medan dinamika para pelaku berawal dari sebuah motivasi yang dilambangkan sebagai V (Vektor) yang menuju kearah tujuan berupa uang tanpa adanya halangan yang berarti atau bondaries yang permeabel dalam lingkungan psikologis subjek penelitian. Dalam tipologi ruang hidup diri pribadi yang dilambangkan sebagai (P) meyakini bahwasannya; 1) Pemberian dianggap sebuah reprensentasi tindakan prososial 2) Pemberian merupakan suatu hal yang dianggap tidak menyalahi nilai dan norma dari individu dan masyarakat 3) Individu memiliki sumber daya dan kesempatan untuk melakukan politik transaksional.
\end{abstract}

Kata Kunci :banal politik transaksional; psikologi; teori medan

\title{
Pendahuluan
}

Politik transaksional merupakan salah satu masalah serius dalam setiap pemilihan umum di Indonesia. Dalam setiap even penyelenggaraan pemilu selalu ditemukan pelanggaran berupa politik transaksional. Bahkan di beberapa daerah politik transaksional menjadi suatu hal yang biasa dan diterima. Hal ini didukung oleh data dari Lingkaran Survei Indonesia (2014) dalam survei nasional terhadap 1890 sampel yang tersebar di seluruh Indonesia, hasilnya menunjukkan bahwa sikap responden terhadap adanya praktik politik transaksional sebesar 57\% menganggap hal tersebut adalah wajar dan tidak akan dilaporkan. Hasil tersebut sejalan dengan temuan oleh Lembaga Indikator Politik Indonesia (2013) dimana hasilnya toleransi pemilih di 39 dapil terhadap politik uang cukup tinggi yaitu 
sebanyak $41,5 \%$ pemilih menilai praktik politik transaksional sebagai suatu kewajaran dan hanya 57,9\% yang menilai politik transaksional tak bisa diterima.

Kemudian temuan KPK yang dikutip dalam berita satu (2014) terhadap Pemilu 2013 bahwa sebanyak 71,72 \% publik menganggap politik uang itu lazim. Dan diperkuat kembali oleh hasil penelitian KPU Kabupaten Bandung (2014) yang menyatakan bahwa kata-kata kunci dari hasil studi tentang pandangan masyarakat tentang politik uang tersebut adalah dianggap suatu 'kewajaran', 'hal yang wajar', 'secara normatif bukan perilaku yang harus dijauhi', 'dipandang sebagai simbol tali asih', dan 'hal yang lumrah'. Begitu pula dengan yang terjadi di Kabupeten Jember. Fenomena politik uang adalah hal yang biasa ditemukan di setiap penyelenggaraan pemilu baik berupa pemilukades, pemilukada, pileg maupun pilpres. Bahkan di salah satu daerah di Kabupaten Jember, dalam studi pendahuluan, peneliti menemukan bahwasannya politik transaksional menjadi bagian substansi dari proses kampanye atau menggerakkan massa, karena menjadi penentu probabilitas terpilihnya calon kandidat.

Hal ini tentu menjadi isu besar bagi bangsa Indonesia pada umumnya dan Kabupaten Jember pada khususnya. Karena menurut Kartono (2015) sebenarnya politik transaksional merupakan salah satu bentuk praktik korupsi. Lebih tepatnya Kartono menyebutkan bahwa politik transaksional masuk ke dalam kategori korupsi politik. Tetapi pandangan masyarakat saat ini justru menganggap bahwa politik transaksional sebagai suatu kewajaran, hal yang wajar, dan hal yang lumrah dilakukan.

Peneliti meminjam istilah Purwantari (2010) yang menyatakan saat ini politik transaksional menjadi 'Banal' atau menjadikan korupsi sebagai sesuatu yang lumrah, biasa, wajar, bahkan menjadi prinsip penggerak kehidupan seharihari. Sasaran politik transaksional diantaranya adalah para pemilih---yang dipengaruhi suaranya. Hasil penelitian oleh Valerina Busco dalam Irawan,dkk (2014) memperlihatkan bahwa kelompok ekonomi menengah bawah merupakan sasaran utama politik transaksional. Hasil yang sama juga diperlihatkan oleh Pedro C Wicente dan Wantchekon dalam Irawan, dkk (2014) dimana riset mereka 
dilakukan di Afrika bahwa sasaran utama praktik politik transaksional adalah mereka yang memiliki tingkat pendidikan rendah dan pendapatan rendah.

Dengan suburnya praktik-praktik politik transaksional mengindikasikan korupsi -khususnya korupsi politik- telah mengakar dan cenderung diterima oleh masyarakat banyak. Legitimasi perilaku korupsi yang mengindikasikan adanya pengaruh lingkungan atau bentuk kompromi dalam interaksi sosial menjadikan politik transaksional sesuatu yang "jamak"e dan "berjamaah" di dalam masyarakat kita. Perilaku korupsi menurut Abidin dan Siswandi (2015) dalam bukunya disebabkan oleh adanya faktor-faktor psikologis diantaranya dipengaruhi oleh motif, locus of control dan trait kepribadian. Sebagaimana varibel psikologis ini diungkapkan oleh Kurt Lewin dalam Baron dkk (2010) bahwa perilaku merupakan fungsi dari individu dan lingkungan. Perilaku korupsi pada dasarnya bukan hanya dipengaruhi lingkungan atau situasi tetapi juga merupakan fungsi dari sesuatu yang melekat dalam diri individu seperti kepribadian, motivasi.

Teori dari Lewin merupakan grand theory dalam bidang keilmuan psikologi yang dikenal sebagai teori medan, menjelaskan bahwasanya setiap perilaku-perilaku yang muncul dari individu merupakan hasil interaksi dari medan ruang kehidupan atau life space. Ruang kehidupan berfungsi dalam tatanan individual dan dalam penelitian ini mencakup gambaran individu yang terusmenerus melakukan politik transaksional meskipun secara nilai dan norma hal tersebut tidak dapat diterima.

Topologi ruang kehidupan oleh Lewin dipilih oleh peneliti karena mampu mengungkapkan mengapa seseorang individu melakukan perilaku politik transksional secara terus-menerus (perilaku banal). Hal ini karena teori ini memiliki kualitas ke-komprehensif-an dalam menjelaskan fenomena yang ada sebab menggali faktor internal dan eksternal yang menjalankan fungsi berperilaku. Selain itu Alwisol (2013) mengemukakan bahwa pada dasarnya teori medan merupakan pencetus dari adanya pendekatan fenomenologi di dalam bidang keilmuan psikologi. Oleh karena itu dengan adanya penelitian ini diharapkan akan menjadi sebuah wawasan baru yang dapat mengungkapkan sisi psikologis seseorang yang melakukan politik transaksional. 


\section{Metode}

Penelitian ini menggunakan metode penelitian deskriptif kualitatif dengan pendekatan fenomenologi. Fenomenologi merupakan pandangan berpikir yang menekankan pada fokus kepada pengalaman-pengalaman subjektif manusia dalam menginterpretasikan dunia (Moleong, 2017). Sebelum menentukan subjek penelitian, pemilihan daerah populasi dilakukan dengan membandingkan beberapa daerah di Kabupaten Jember dimana yang terpilih adalah daerah dengan kontestasi politik yang paling tinggi. Hal ini dilakukan dengan membandingkan data DPT (Daftar Pemilih Tetap) pada Pemilu tahun 2019 pada situs KPU (2019) sejumlah 341.988 suara namun dengan perolehan kursi yang relatif sedikit sejumlah 9 kursi. Maka daerah A terpilih sebagai populasi dalam penelitian.

Proses pengambilan sampel dilakukan dengan teknik purposive sampling, dimana sampel yang diambil adalah subjek yang melakukan praktik politik transaksional yaitu para pemilih atau penerima. Kriteria inklusi yang ditentukan peneliti berupa sampel yang lebih dari dua kali melakukan praktik politik uang, baik dalam pemilu kepala desa, pemilu legislatif, pemilu kepala daerah maupun pemilu presiden. Saat data yang dikumpulkan sudah jenuh selanjutnya penentuan sampel menggunakan tehnik snowball dimana subjek merekomendasikan subjek lain yang terlibat dalam praktik politik transaksional. Sehingga hasil akhir didapatkan data jenuh dari lima subjek penelitian.

Instrumen penelitian ini adalah diri peneliti, maka untuk menjaga validitas dan reabilitas penelitian teknik pengumpulan data menggunakan guide atau panduan wawancara serta catatan lapangan untuk observasi non partisipan. Pertama-tama peneliti melakukan diskusi dan bimbingan sehingga menghasilkan guide atau panduan wawancara dan observasi yang akan dilakukan kepada sampel penelitian. Setelah membuat guide, peneliti terjun langsung ke dalam lingkungan politik yang melakukan politik transaksional. Pertama-tama peneliti membangun rapport terlebih dahulu untuk membang kepercayaan sampel terhadap peneliti. Saat membangun rapport peneliti melakukan observasi non partisipan terhadap 
kegiatan yang dilakukan sampel dalam kegiatannya sebagai simpatisan politik dan hubungannya dengan aktor politik.

Setelah itu peneliti melakukan FGD (Focused Group Discussion) dengan beberapa orang dalam populasi yang melakukan politik transaksional untuk serta untuk melakukan triangulasi data. FGD dilakukan dengan melibatkan beberapa tokoh politik, aktor politik dan masyarakat untuk membentuk sebuah pemahaman tentang bagaimana politik transaksional itu bekerja. Setelah dilakukan FGD peneliti melaksanakan wawancara mendalam berdasarkan guide yang telah dibuat untuk memperoleh gambaran dinamika psikologi dari para pelaku terhadap politik transaksional. Selanjutnya hasil wawancara yang diperoleh dituliskan ke dalam verbatim dan dianalisis lebih lanjut menggunakan analisis fenomenologi oleh Sanders (1982) untuk kemudian dirumuskan kedalam teori Medan yang menghasilkan pembahasan sesuai dengan yang tertulis dalam pembahasan.

\section{Hasil Dan Pembahasan}

Penelitian ini dihimpun dari proses wawancara dan observasi terhadap lima subjek yang memenuhi kriteria sampel sebagai pelaku politik transaksional yang telah menjadi 'banal'. Defenisi operasional 'banal' yaitu bahwa perilaku tertentu dianggap sebagai sebuah kewajaran atau dalam tolak ukur perilaku hal tersebut telah menjadi rutinitas atau selalu dilakukan. Adapun gambaran demografi sampel yang diteliti sebagai berikut:

Tabel 1. Gambaran Demografi Sampel

\begin{tabular}{ccccccc}
\hline Sampel & $\begin{array}{c}\text { Nama } \\
\text { (inisial) }\end{array}$ & Usia & $\begin{array}{c}\text { Jenis } \\
\text { Kelamin }\end{array}$ & $\begin{array}{c}\text { Pendidikan } \\
\text { Terakhir }\end{array}$ & Suku & Pekerjaan \\
\hline 1 & Tn. M & 35 th & L & SD & Jawa & Buruh lepas \\
\hline 2 & Tn. D & 42 th & L & SD & Jawa & Kuli Bangunan \\
\hline 3 & Ny. K & 47 th & P & SMA & Madura & Ibu Rumah Tangga \\
\hline 4 & Tn. C & 57 th & L & SMP & Jawa & Petani \\
\hline 5 & Tn. U & 43 th & L & SD & Jawa & Petani \\
\hline
\end{tabular}

Gambaran demografi pada subjek bahwasannya tingkat pendidikan mereka rata-rata hanya sampai pada jenjang Sekolah Dasar. Kemudian pekerjaan yang dilakukan merupakan pekerjaan dengan penghasilan rata-rata dibawah UMR 
(Upah Minimum Regional) di Kabupaten Jember. Selain itu subjek pada umumnya berada pada tingkatan usia paruh baya atau dewasa madya serta berjenis kelamin laki-laki. Terakhir suku mayoritas pada sampel adalah suku Jawa dimana merupakan identitas budaya yang dianut sehari-hari.

Dari hasil penelitian yang diperoleh, semua subjek penelitian menyatakan bahwa politik transaksional dewasa ini merupakan hal yang umum dilakukan di masyarakat bahkan menjadi bagian yang tidak terpisahkan. Dari hasil wawancara politik transaksional memiliki pemaknaan yang berbeda bagi masing-masing individu contohnya pada subjek 1 menyatakan bahwa politik transaksional dimaknai sebagai sebuah 'sodaqoh' dari seseorang yang akan menjadi calon pemimpin. Sodaqoh dalam agama Islam merupakan konotasi positif dimana merupakan kewajiban seorang muslim untuk membantu sesama dalam bentuk uang maupun barang. Subjek 2 menyatakan bahwa politik transaksional dimaknai sebagai sebuah 'uang lelah' bagi mereka yang menggunakan hak pilihnya. Hal ini dikarenakan subjek 2 mengatakan bahwa orang kebyakan akan memilih bekerja daripada mencoblos di TPS, maka uang dianggap sebagai kompensasi saat tidak pergi bekerja. Sedangkan subjek 3 menganggap bahwa pemberian yang diberikan dalam politik transaksional sebagai sebuah 'hadiah' yang bermakna penghargaan terhadap kelompok masyarakat. Kemudian sampel 4 dan 5 memaknai uang yang umumnya digunakan dalam politik transaksional sebagai sebuah 'tali asih' dari seseorang yang ingin mendapatkan kekuasaan.

Dalam teori Lewin menggambarkan manusia sebagai individu yang hidup dalam lingkungan psikologis, dengan pola hubungan dasar tertentu. Pendekatan matematis yang dipakai Lewin untuk menggambarkan ruang hidup disebut topologi. Lewin (dalam Abidin \& Siswadi, 2015) menjelaskan bahwa perilaku pada dasarnya merupakan fungsi dari individu dan lingkungan atau $B=f(I+E)$. $\mathrm{B}=$ Behavior, $\mathrm{I}=$ Individual dan $\mathrm{E}=$ Environment . Maka di dalamnya dirumuskan sebuah aspek-aspek psikologis yang mana oleh Ajzen (2005) diturunkan ke dalam teori praktis yaitu TPB atau (Theory of Planned Behaviour). Di dalam teori ini memuat aspek-aspek internal dan eksternal manusia yang menjadi indikator perilaku seperti sikap, norma, dan kontrol perilaku. 
Dari hasil wawancara diperoleh bahwa sikap yang dimiliki oleh subjek adalah positif terhadap perilaku politik transasksional. Sikap yang dianut terdiri dari keyakinan terhadap konsekuensi perilaku secara kognitif dan afektif. Secara kognitif subjek menganggap bahwa politik transaksional memiliki manfaat positif bagi dirinya hal ini karena mereka dapat merasakan secara langsung dampak diberikannya uang atau barang. Selain itu secara afektif mereka merasakan pengalaman yang menyenangkan dengan adanya politik transaksional, subjek merasakan bahwa mereka 'terbantu' dan hal ini menunjukkan adanya ketidakberdayaan dari mereka dalam menghadapi politik transaksional. Di dalam teori Lewin sikap ini dirumuskan ke dalam valensi atau keyakinan yang positif atau negatif terhadap perilaku politik transaksional. Dan hasilnya keyakinan subjek adalah positif.

Perilaku politik transaksional terjadi tak lepas karena adanya sebuah persepsi mengenai harapan orang lain terhadap individu atau norma subjektif. Persepsi ini berupa hubungan secara vertikal dan horizontal. Dimana hubungan secara vertikal yaitu kedekatan terhadap individu atau kelompok yang dianggap lebih tinggi, sedangkan hubungan horizontal yaitu kedekatan dengan individu lain atau kelompok yang memiliki status sosial yang dianggap sama. Secara vertikal subjek mengharapkan ditolong atau dalam aspek keyakinan ada perasaan tidak berdaya terhadap aktor politik. Maka figur aktor politik diharapkan menjadi 'penolong' atau melakukan tindakan 'prososial'_tindakan yang diharapkan oleh masyarakat. Sedangkan secara horizontal subjek melihat banyaknya praktikpraktik politik transaksional yang dilakukan oleh masyarakat bahkan sejak sebelum pemilu terbuka yang kemudian memengaruhi subjek untuk meniru atau melakukan 'modelling' terhadap perilaku politik transaksional. Di dalam teori Lewin konsepsi norma subjektif dirumuskan ke dalam sebuah bondaris atau garis pemisah diantara faktor-faktor psikologis dimana bondaris ini bersifat mudah ditembus atau artinya perilaku politik transasksional merupakan hal yang bisa dilakukan dengan mudah oleh subjek.

Aspek selanjutnya menurut Ajzen (2005) adalah persepsi kontrol perilaku yang ditentukan oleh keyakinan individu mengenai kemampuan untuk melakukan 
perilaku berupa; sumber daya dan kesempatan. Sumber daya dalam politik transaksional mirip dengan konsep self efficacy atau efikasi diri dimana konsepsi ini merujuk kepada keyakinan untuk sukses dalam melakukan suatu kegiatan. Subjek meyakini sesuai dengan pengalamannya ketika melaksanakan politik transasksional dirinya tidak akan menemui kendala atau akibat yang negatif. Keyakinan ini memunculkan supply and demand dimana baik akor politik maupun pemilih sama-sama membutuhkan satu sama lain. Aktor politik membutuhkan jabatan atau kekuasaan sedangkan pemilih membutuhkan manfaat praktis dari aktor politik itu sendiri. Selain itu adanya kesempatan dimana subjek tidak memiliki barier apapun dalam menghadapi situasi politik transaksional. Pada umumnya situasi pemberian 'uang' dilakukan secara langsung oleh tim sukses yang mendatangi pemilih. Kesempatan untuk menerima lebih besar karena unsur privasi dari proses pemberian tersebut.

Untuk lebih memahami interaksi ruang kehidupan dalam event politik transaksional maka peneliti melalui tinjauan teori Lewin menjelaskan dalam tipologi ruang hidup yang digambarkan sebagai berikut:

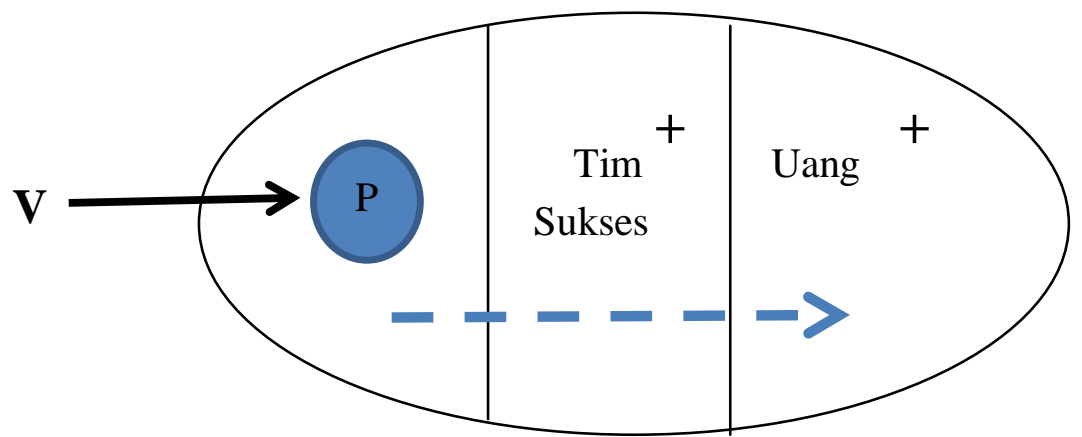

Gambar 1. Tipologi Ruang Hidup teori Lewin

Vektor dalam ruang hidup adalah motivasi dari individu, hal ini dapat bervariasi namun secara garis besar subjek memiliki latar belakang perekonomian menengah kebawah sehingga keperluan untuk memenuhi kebutuhan lebih tinggi. Hal tersebut digambarkan ke dalam sebuah vektor sebagai garis yang panjang, yang menunjukkan motivasi yang tinggi ke arah goal atau tujuan. Kemudian region di dalam event politik transaksional dibagi menjadi tiga bagian yakni diri pribadi dilambangkan sebagai $\mathrm{P}$, tim sukses, serta goal atau tujuan yaitu uang. 
Diri pribadi meliputi kepribadian dan pengalaman individu, tim sukses adalah faktor psikologis yang memerantarai adanya politik transaksional, kemudian goal atau tujuan dari para pelaku politik transaksional yaitu uang. Temuan menarik diperoleh peneliti dari hasil wawancara yaitu politik transaksional yang dilakukan pemilih menekankan pada pemberian 'uang' daripada pemberian barang. Hal ini berarti bahwa seseorang akan lebih dipilih oleh subjek bila memberikan uang daripada memberi barang seperti kaos, stiker dan lain-lain.

Kedua region, baik tim sukses dan uang bervalensi positif karena subjek tertarik untuk mendekatinya. Valensi ini berasal dari keyakinan subjek bahwa pemberian pada politik transaksional diyakini sebagai suatu hal yang positif bagi mereka. Garis panah yang putus-putus disebut sebagai lokomosi. Lokomosi adalah arah yang menunjukkan kemana pikiran dari pelaku akan menuju. Dalam event politik transaksional lokomosi bergerak dari person atau $\mathrm{P}$ mengarah menuju ke goal atau tujuan berupa Uang. Dalam tipologi garis lokomosi tanpa hambatan menuju langsung ke goal dengan tanpa halangan atau bondaris yang permeabel. Hal ini dikarenakan norma subjektif individu meyakini bahwa perilaku politik transaksional dilakukan juga oleh masyarakat kebanyakan sehingga secara normatif tidak ada penghalang perilaku tersebut untuk tidak dilakukan. Dari topologi Lewin dapat disimpulkan bahwa seseorang individu melakukan politik transaksional dikarenakan oleh dorongan internal vektor yang mengarahkan individu melewati region yang permeabel untuk menuju goal berupa uang yang memiliki valensi positif bagi pelakunya.

\section{KESIMPULAN}

Berdasarkan hasil penelitian dalam tinjauan teori Lewin bahwa dalam tipologi ruang hidup, subjek akan mendapatkan uang atau melakukan politik transaksional berawal dari adanya dari sebuah motivasi yang dilambangkan sebagai V (Vektor) yang menuju kearah tujuan berupa uang tanpa adanya halangan yang berarti atau bondaries yang permeabel dalam lingkungan psikologis subjek penelitian. Dalam tipologi ruang hidup diri pribadi yang dilambangkan sebagai (P) meyakini bahwasannya; Yang pertama bahwa 
pemberian dianggap sebuah reprensentasi tindakan prososial dari aktor politik. Persepsi subjek bahwa pemberian dianggap sebagai suatu shodaqoh, tali asih serta hadiah yang memang harus diterima dan bukan suatu pelanggaran hukum atau hal yang negatif. Yang kedua, pemberian merupakan suatu hal yang dianggap tidak menyalahi nilai dan norma dari individu dan masyarakat. Subjek memiliki persepsi dalam hubungan vertical berupa kebutuhan untuk ditolong dan hubungan horizontal sebagai perilaku modeling terhadap politik transaksional. Yang ketiga individu memiliki sumber daya dan kesempatan untuk melakukan politik transaksional. Dimana sumber daya berupa efikasi diri terhadap politik transaksional dan kesempatan berupa praktik privat dari politik transaksional.

\section{SARAN}

Hasil penelitian ini dapat menggambarkan dinamika psikologi dari para pemilih dimana nantinya dapat dijadikan sebagai tambahan pengetahuan dan mengembangkan konsep teori tentang psikologi korupsi yang membahas korupsi politik. Dengan mengetahui gambaran psikologis seseorang yang melakukan politik transaksional diharapkan menjadi sebuah pertimbangan bagi pengampu kebijakan khususnya penyelenggara pemilu dan inisiator Undang-Undang sehingga dapat dirumuskan sebuah sistem, peraturan dan kebijakan yang dapat mengatasi permasalahan banal politik transaksional secara efektif dan efisien. Kemudian saran bagi peneliti selanjutnya diharapkan agar dapat menggali faktorfaktor dari temuan penelitan untuk dijadikan penelitian kuantitatif sehingga hasil penelitian tersebut dapat digeneralisasikan.

\section{DAFTAR PUSTAKA}

Ajzen, I. (2005). Attitudes, personality, and behavior. McGraw-Hill Education (UK).

Alwisol, M. (2013). Psikologi kepribadian. Malang: Universitas Muhammyadiah Malang. 
Abidin,Z.,\&A.G.P. Siswandi. 2015. Psikologi Korupsi. Bandung : PT Remaja Rosdakarya.

Beritasatu. 2014. KPK : 71\% Masyarakat Politik Uang Itu Wajar. https://id.beritasatu.com/home/kpk-71-masyarakat-anggap-politik-uangwajar/80596. diakses 28 Desember 201.

Hutomo, Radityo Rizki. 2014. Perilaku Memilih Warga Surabaya Dalam Pemilu Legislatif 2014 (Hubungan Kesuaian Program Kandidat, Kampanye, Identifikasi Partai dan Pemberian Imbalan Uang dalam Menentukan Pilihan Partai Politik dalam Pemilu Legislatif 2014). Jurnal Politik Muda, Vol. 4 No. 1, Januari - Maret 2015, 50 - 60

Irawan,dkk. 2014. Korupsi Pemilu. Jakarta: ICW.

Kartono, K. (2015). Patologi sosial jilid 1. Jakarta: PT Raja Grafindo Persada.

KPU, Bandung Barat. 2014. Laporan Riset : Politik Uang pada Pemilu Legislatif 2014 di Kabupaten Bandung Barat. Bandung : KPU.

LIP.2013. Laporan Konpers Rilis Survei Sikap dan Perilaku Pemilih terhadap Money Politics. http://www.indikator.co.id/news/details/1/41/LaporanKonpers-Rilis-Survei-Sikap-dan-Perilaku-Pemilih-terhadap-MoneyPolitics-. Diakses 28 Desember 2018.

LSI.2014. Persepsi dan Opini Publik terhadap Penyelenggara Pemilu. http://www.lsi.or.id/riset/433/Opini_Publik_thdp_penyelenggara_PEMIL U. Diakses 29 Desember 2018.

Moleong, J. (2017). Lexy. Metodologi Penelitian Kualitatif. Bandung : PT Rosdakarya.

Muhtadi, B. (2013). Politik Uang dan Dinamika Elektoral Di Indonesia: Sebuah Kajian Awal Interaksi Antara "Party-Id" dan Patron-Klien. Jurnal Penelitian Politik, 10(1), 17.

Purwantari, B. I. Mempertanyakan Banalitas Korupsi. Kompas, 30/8/2010. 